\title{
Employment protection legislation in central and east European countries 1
}

\begin{abstract}
This article presents updated indicators of employment protection legislation for several central and eastern European countries according to OECD methodology. Common patterns and outliers are identified and additional information is provided to interpret correctly the strictness of the regulatory environment. The aim is to provide some hard evidence for the debate regarding the interface between employment protection legislation and labour markets and welfare, based on the legislations applying in central and east European countries at the end of 2003. The article focuses on the 22 aspects of employment regulation encompassed within the OECD model, examining how each relates to the employment protection legislation in force in each country, and scores each one based on the relative restrictiveness of the regulation. The article concludes that the occurrence of informal arrangements complicates the picture but that this does not invalidate the usefulness of examining formal rules in detail
\end{abstract}

Keywords: employment protection legislation, central and eastern Europe, regulation, labour markets, contracts of employment, dismissal, notice and severance, redundancy, trial periods, trade unions

\section{Introduction}

The effects of employment protection legislation on labour market and welfare have been the subject of an intense theoretical and policy debate. ${ }^{2}$ Comprehensive and updated indicators covering an extended set of countries are necessary to inform the debate. The World Bank provides a measure of regulation concerning the hiring and firing of workers for a broad set of countries (World Bank, 2003, 2004c; and Botero et al. 2004), while the OECD has calculated wide-ranging indicators in several waves for member countries, covering different aspects of labour market regulation (OECD, 1999, 2004b).

In their analysis of labour markets in central and eastern European economies, Cazes and Nesporova (2003) underline the need to have at hand updated measures of the strictness of employment protection legislation for more countries in the region. The purpose of this paper is to present employment protection legislation indicators for a wide group of central and east European countries for recent years. The analysis of

1 The author would like to thank Sandrine Cazes and Alena Nesporova for their useful comments on an earlier draft of this article.

2 See OECD (2004b) for a review. 
the impact of employment protection on labour market outcomes and welfare using the indices computed here, as well as a comparison of employment protection legislation in different periods, has been conducted by Cazes and Nesporova (2007).

The methodology used is that which has been developed by the OECD (for details, see OECD, 1999, Chapter 2; and OECD, 2004b, Chapter 2). In principle, besides labour legislation, information on the prevailing provisions in collective labour contracts and on judicial enforcement should also be used. However, due to the unavailability of consistent data for the whole group of countries, only those regulations contained in the Labour Codes and other relevant laws have been considered here. ${ }^{3}$

The OECD methodology puts a great deal of emphasis on strictly defining the relevant regulation; however, some scope for interpretation is unavoidable. The OECD has calculated indices for employment protection legislation for 2003 for Czech Republic, Hungary, Poland and Slovak Republic (OECD, 2004b). These calculations are not identical to the ones presented here, although they are very similar. In some cases, the difference is due to different basic information; ${ }^{4}$ in others, to different interpretations of the same information. ${ }^{56}$

The indicators calculated here refer to the legislation in force on 31 December 2003 with the exception of Poland, where 31 December 2004 is the threshold. Changes in the value of the index for 2004 are indicated in a note below each table.

Besides the calculated values of the indicators, a brief summary of the regulation is provided, underlying the common patterns and outliers. The approach is to emphasise all the information that may be relevant with which correctly to interpret the strictness of the regulation. The indices developed by the OECD are useful precisely because they compress information, but they should be handled with care. Thus, for instance,

3 See the Appendix for the list of legislation consulted.

4 For instance, the Slovakian Labour Code reads: 'An employer may give an employee notice, unless given on grounds of the unsatisfactory fulfilment of working tasks, for less serious breaches of labour discipline or for reasons for which the immediate termination of employment relationship is applicable, only in such cases where a) the employer does not have the possibility to employ the employee further, not even for reduced working time, in the place which was agreed as the place of work performance, and b) the employee is not willing to shift to other appropriate work which has been offered to him/her by the employer at the place of work agreed as the place of work performance.' (Article $63 \$ 2$, italics added). However, this is not reported in the OECD's A detailed description of employment protection regulation in force in 2003 (OECD, 2004a) and indicator RC3A (the definition of unfair dismissal) for Slovakia in 2003 is, consistent with this omission, but differently from here, scored 0 by the OECD.

5 For instance, the Slovakian Labour Code reads 'On the termination of the employment relationship, an employee shall be entitled to a severance allowance upon the termination of employment at a minimum sum of a two-fold of his average monthly earnings if he agrees with the termination of the employment relationship before the beginning of the expiry of the notice period [...]' (Article 76§2). The OECD partly acknowledges this (OECD, 2004a: page 6, note h), but fails to take into account that severance and notice are substitutes and not complements; and, differently from here, assigns both two months of notice and two months of severance in the case of redundancy.

6 A formal difference with the OECD indicators is that TC1A and TC2A have been inverted here so as to keep the convention that higher scores represent stricter regulation. 
using the indices calculated here in a study concerning the size of firms would be misleading without taking proper care that, in some countries, small firms are exempt from some of the regulation. ${ }^{7}$ The OECD methodology does not distinguish between firms of different size, so this information is provided in the commentary.

\section{Employment protection legislation indicator}

The indicator developed by the OECD is based on 22 aspects of employment regulation. Each of these is assigned a score, following the convention that higher numbers mean more restrictive regulations. These building blocks are then aggregated into various intermediate indicators, taking values between 0 and 6 , and successively aggregated into a summary indicator, also within the same range.

Table 1 below presents the headline index and the three main intermediate indicators. The first of these, i.e. regular contracts, concerns regulation in the case of the dismissal on personal grounds or individual redundancy, but without fault, of an employee on an open-ended contract. The next, temporary contracts, regards regulation on the use of time-limited contracts. The last, collective dismissal, considers rules in the case of mass redundancies. Each of these intermediate indicators is analysed in detail in the following sections.

Table 1 - The employment protection legislation index and the three main intermediate indicators

\begin{tabular}{|c|c|c|c|c|c|c|c|c|c|c|c|c|c|}
\hline & & & y & $\cong$ & U & 됟 & $\geqq$ & 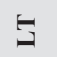 & $\vec{a}$ & $\stackrel{D}{\simeq}$ & $\frac{1}{n}$ & $\bar{n}$ & $\overleftrightarrow{\zeta}$ \\
\hline & & Weight & 2.0 & 2.7 & 2.0 & 2.3 & 1.6 & 2.8 & 2.2 & 1.9 & 1.7 & 2.6 & 2.1 \\
\hline $\begin{array}{l}\text { Regular } \\
\text { contracts }\end{array}$ & $\mathrm{RC}$ & $5 / 12$ & 2.1 & 2.7 & 3.3 & 2.7 & 2.2 & 2.9 & 2.0 & 3.2 & 2.7 & 2.7 & 3.3 \\
\hline $\begin{array}{l}\text { Temporary } \\
\text { contracts }\end{array}$ & $\mathrm{TC}$ & $5 / 12$ & 0.9 & 2.8 & 0.5 & 1.3 & 0.4 & 2.4 & 2.0 & 0.8 & 0.3 & 2.3 & 1.8 \\
\hline $\begin{array}{l}\text { Collective } \\
\text { dismissal }\end{array}$ & $\mathrm{CD}$ & $2 / 12$ & 4.1 & 2.5 & 2.6 & 4.0 & 3.4 & 3.6 & 3.3 & 1.9 & 3.0 & 3.3 & 0.0 \\
\hline
\end{tabular}

Note: for 2004:

$E P L-C Z: 2.4 ; E E: 2.4$

$T C-C Z: 1.4 ; E E: 1.5$

\section{Regular employment}

The index for dismissal in the case of regular contracts is made up of three sub-indices, each having equal weight. The sub-index on procedural inconveniences refers to the

7 Boeri and Jimeno (2005) exploit exactly this feature to investigate the impact of employment protection legislation on dismissal probabilities and the equilibrium size distribution of firms. 
procedural requirements behind the implementation of a dismissal. Another sub-index regards notice and severance pay in the case of individual dismissals. The third subindex concerns the definition and consequences of unfair dismissal and the length of the trial period. The table below presents these indices, followed by a description of the basic aspects of the regulation making up each sub-index.

Table 2 - Dismissals from regular employment

\begin{tabular}{|c|c|c|c|c|c|c|c|c|c|c|c|c|c|}
\hline & & & ט. & $\underline{\underline{\Xi}}$ & U & 됟 & $\geqq$ & 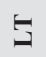 & $\vec{a}$ & $\stackrel{2}{\simeq}$ & $\frac{v}{n}$ & $\bar{n}$ & 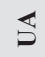 \\
\hline & & Weight & 2.1 & 2.7 & 3.3 & 2.7 & 2.2 & 2.9 & 2.0 & 3.2 & 2.7 & 2.7 & 3.3 \\
\hline $\begin{array}{l}\text { Procedural } \\
\text { incon- } \\
\text { veniences }\end{array}$ & $\mathrm{RC} 1$ & $1 / 3$ & 2.0 & 3.0 & 3.5 & 2.0 & 1.5 & 2.0 & 2.5 & 2.0 & 3.0 & 3.0 & 3.0 \\
\hline $\begin{array}{l}\text { Notice and } \\
\text { severance pay }\end{array}$ & $\mathrm{RC} 2$ & $1 / 3$ & 1.8 & 2.0 & 2.7 & 2.5 & 2.0 & 3.2 & 1.4 & 3.3 & 1.8 & 1.8 & 2.5 \\
\hline $\begin{array}{l}\text { Difficulty of } \\
\text { dismissal }\end{array}$ & $\mathrm{RC} 3$ & $1 / 3$ & 2.5 & 3.0 & 3.8 & 3.8 & 3.0 & 3.5 & 2.0 & 4.3 & 3.3 & 3.3 & 4.3 \\
\hline
\end{tabular}

\section{Procedural inconveniences}

In all countries except Ukraine, notice has to be delivered in written form. Only Bulgaria, Czech Republic, Russia and Ukraine do not explicitly require the reason for the dismissal to be provided. Employees' representatives, namely the trade union or the works council, need to be involved in the standard ${ }^{8}$ procedure of dismissal. Hungary and Bulgaria represent an exception in this regard, while in Slovenia a request from the employee is necessary. In some countries also, the involvement of the employment office is required. In Estonia, if the employment relationship is terminated because of liquidation or the lay-off of employees, the employment office has to be informed while in Ukraine, the same has to be done where the firm cannot offer another job or the worker refuses it.

In general, third parties have simply to be informed. However, employee representatives play a larger role in some countries. In Croatia and Czech Republic, notice must be discussed with them. This is also the case in Lithuania for dismissals on economic or technological grounds or due to the restructuring of the workplace. In Slovakia, there is a legal obligation to negotiate notice with employee representatives.

8 Concerning the dismissal of workers not belonging to protected categories (e.g. pregnant women or trade union officials). 
Table 3 - Procedural inconveniences

\begin{tabular}{|c|c|c|c|c|c|c|c|c|c|c|c|c|c|}
\hline & & & U & $\cong$ & N & 닏 & $\geqq$ & 5 & 2 & $\vec{z}$ & ๓ै & $\bar{n}$ & $\overleftrightarrow{s}$ \\
\hline & & Weight & 2.0 & 3.0 & 3.5 & 2.0 & 1.5 & 2.0 & 2.5 & 2.0 & 3.0 & 3.0 & 3.0 \\
\hline Procedures & $\mathrm{RC} 1 \mathrm{~A}$ & $1 / 2$ & 3.0 & 4.0 & 4.0 & 4.0 & 2.0 & 3.0 & 4.0 & 4.0 & 4.0 & 5.0 & 5.0 \\
\hline $\begin{array}{l}\text { Delay in } \\
\text { giving notice }\end{array}$ & $\mathrm{RC} 1 \mathrm{~B}$ & $1 / 2$ & 1.0 & 2.0 & 3.0 & 0.0 & 1.0 & 1.0 & 1.0 & 0.0 & 2.0 & 1.0 & 1.0 \\
\hline
\end{tabular}

An even stronger role for trade unions is envisaged in the Ukrainian labour code, where the termination of the labour contract of a trade union member generally requires their preliminary consent. In Bulgaria, the labour code explicitly allows for collective agreements to require the prior consent of the trade union in cases of staff cuts or a reduction in the volume of work. In Slovenia, the consent of the trade union is not required, but it can oppose termination for reason of incapacity or fault and, in this case, the employee may require that the termination of the contract does not become effective until the expiry of the term for judicial protection.

The involvement of employee representatives before the giving of notice is subject to precise time limits in Croatia (eight days for the works council to submit its observations); in Slovakia (ten days for negotiations to take place); and in Ukraine (eighteen days for the trade union to examine the case and inform the employer of its decision). In Poland, the trade union has the right only to be informed about the intended notification, but the delivery of the notice is suspended for five days after information has been given in writing, during which period the trade union may present written objections. In Slovenia, the formal opposition of the trade union must be registered within eight days of receiving the information, but this does not delay the delivery of notice by the employer.

In cases of the delivery of notices of dismissal on personal grounds, Croatia, Hungary and Slovenia explicitly require that the employee is given the opportunity to provide a defence. A written warning must have been delivered during the previous twelve months in the Czech Republic and the previous six months in Slovakia.

\section{Notice and severance}

All the countries regulate notice periods in the case of dismissal and all but Poland regulate severance pay.

The labour code usually provides exact figures, or minimum thresholds, although this is not the case in Bulgaria and Russia, where severance pay is intended to compensate for loss of earnings arising from unemployment subject to a maximum threshold. A maximum notice period that can be agreed upon by the parties is set down in Bulgaria and Hungary, while an upper limit to severance pay exists in Croatia and in Slovenia.

There is an even share between countries where seniority changes the position and where rules are the same irrespective of length of service. In the first group, some 
countries differentiate only among a few categories. In Slovakia, for instance, the difference is between those whose years of service are above or below five years. Other systems are much more detailed. In Hungary, there are seven different periods of notice and six amounts of severance payment, depending on length of service. The regulation of the severance allowance in Slovenia and Croatia is peculiar in that compensation is a given fraction of monthly salary for each year of service, with the additional feature in Slovenia that the fraction itself depends on seniority. ${ }^{9}$ In Lithuania, severance pay alone depends on seniority, while in Poland it is just the notice period. In Estonia, the system differs depending on the reasons for which the employment contract is terminated. Both notice and severance depend on seniority if termination is due to the layoff of employees or age; in contrast, length of service does not matter if it is unsuitability or the long-term incapacity of the employee that are the causes of the dismissal.

\section{Table 4 - Notice and severance pay}

\begin{tabular}{|c|c|c|c|c|c|c|c|c|c|c|c|c|c|}
\hline & & & U્ય & $\cong$ & $\mathbf{U}$ & 되도 & $\geqq$ & 5 & 2 & $\ddot{\approx}$ & $\frac{v}{n}$ & $\bar{n}$ & $\overleftrightarrow{b}$ \\
\hline & & Weight & 1.8 & 2.0 & 2.7 & 2.5 & 2.0 & 3.2 & 1.4 & 3.3 & 1.8 & 1.8 & 2.5 \\
\hline $\begin{array}{l}\text { Notice } \\
\text { period after } 9 \\
\text { months }\end{array}$ & RC2A1 & $1 / 7$ & 3.0 & 2.0 & 6.0 & 4.0 & 3.0 & 6.0 & 3.0 & 6.0 & 3.0 & 3.0 & 6.0 \\
\hline $\begin{array}{l}\text { Notice } \\
\text { period after } 4 \\
\text { years }\end{array}$ & $\mathrm{RC} 2 \mathrm{~A} 2$ & $1 / 7$ & 2.0 & 3.0 & 5.0 & 3.0 & 2.0 & 4.0 & 5.0 & 4.0 & 2.0 & 2.0 & 4.0 \\
\hline $\begin{array}{l}\text { Notice } \\
\text { period after } \\
20 \text { years }\end{array}$ & $\mathrm{RC} 2 \mathrm{~A} 3$ & $1 / 7$ & 1.0 & 2.0 & 1.0 & 1.0 & 2.0 & 2.0 & 2.0 & 1.0 & 1.0 & 1.0 & 1.0 \\
\hline $\begin{array}{l}\text { Severance } \\
\text { pay after } 9 \\
\text { months }\end{array}$ & $\mathrm{RC} 2 \mathrm{~B} 1$ & $4 / 21$ & 2.0 & 0.0 & 2.0 & 3.0 & 0.0 & 2.0 & 0.0 & 4.0 & 2.0 & 0.0 & 2.0 \\
\hline $\begin{array}{l}\text { Severance } \\
\text { pay after } 4 \\
\text { years }\end{array}$ & $\mathrm{RC} 2 \mathrm{~B} 2$ & $4 / 21$ & 2.0 & 3.0 & 2.0 & 3.0 & 2.0 & 4.0 & 0.0 & 4.0 & 2.0 & 2.0 & 2.0 \\
\hline $\begin{array}{l}\text { Severance } \\
\text { pay after } 20 \\
\text { years }\end{array}$ & $\mathrm{RC} 2 \mathrm{~B} 3$ & $4 / 21$ & 1.0 & 2.0 & 1.0 & 1.0 & 3.0 & 2.0 & 0.0 & 1.0 & 1.0 & 3.0 & 1.0 \\
\hline
\end{tabular}

The reasons for termination matter in other countries as well. In the Czech Republic, notice is one month longer if the dismissal is due to relocation, technological or organisational changes. In Slovenia, another source of differentiation besides seniority

9 Thus, in Slovenia, for seniority of between one and five years, severance pay is one-fifth of the monthly wage for each year of employment, increasing to one-quarter for seniority of between five and fifteen years and one-third for those above fifteen years (Employment Relationships Act, Art. 109). 
is whether the dismissal is due to business reasons or incapacity. In Bulgaria, Czech Republic, Estonia, Russia and Slovakia, severance pay depends on the reasons for the dismissal, with redundancy due to economic reasons usually implying a more advantageous treatment. In some countries, there are specific rules for workers reaching or approaching qualification for retirement. Notice is longer in Croatia for workers who are over 50 and 55, as it is also in Lithuania for workers due to qualify for an old age pension within five years. In the latter case, Hungary prescribes an additional severance payment, while no payment is due to workers already qualifying as pensioners. In contrast, Bulgaria reserves particularly favourable conditions for these workers, while separate rules on severance pay exist also in Slovakia. A peculiarity of the Slovak labour code is that entitlement to severance allowance develops only if the employee agrees with the termination of the employment relationship prior to the commencement of the period of notice, thus making notice and severance pay substitutes, rather than complements for each other as in other countries.

\section{Difficulty of dismissal}

Grounds for dismissal are regulated with different degrees of detail. The Bulgarian and Russian labour codes contain a long list of specific cases in which a labour agreement can be terminated by the employer, while the Hungarian and Lithuanian ones simply state the broad principles which apply as regards when a dismissal may be justified. The Polish code is particular in that it refrains from positively regulating when a dismissal is allowed, stating instead that 'Each party may terminate a contract of employment by notice' (Art. 32§1) and including some exceptions for specific categories.

\section{Table 5 - Difficulty of dismissal}

\begin{tabular}{|c|c|c|c|c|c|c|c|c|c|c|c|c|c|}
\hline & & & טِ & $\cong$ & U & 됟 & $\mathfrak{\Xi}$ & 5 & $\bar{a}$ & $\mathfrak{z}$ & $\frac{1}{n}$ & $\bar{n}$ & 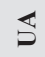 \\
\hline & & Weight & 2.5 & 3.0 & 3.8 & 3.8 & 3.0 & 3.5 & 2.0 & 4.3 & 3.3 & 3.3 & 4.3 \\
\hline $\begin{array}{l}\text { Definition } \\
\text { of unfair } \\
\text { dismissal }\end{array}$ & $\mathrm{RC} 3 \mathrm{~A}$ & $1 / 4$ & 0.0 & 2.0 & 4.0 & 4.0 & 0.0 & 4.0 & 0.0 & 6.0 & 4.0 & 3.0 & 6.0 \\
\hline $\begin{array}{l}\text { Trial } \\
\text { period }\end{array}$ & $\mathrm{RC} 3 \mathrm{~B}$ & $1 / 4$ & 3.0 & 3.0 & 4.0 & 4.0 & 4.0 & 4.0 & 4.0 & 4.0 & 4.0 & 3.0 & 4.0 \\
\hline $\begin{array}{l}\text { Compen- } \\
\text { sation }\end{array}$ & $\mathrm{RC} 3 \mathrm{C}$ & $1 / 4$ & 1.0 & 3.0 & 1.0 & 1.0 & 4.0 & 2.0 & 0.0 & 1.0 & 1.0 & 3.0 & 1.0 \\
\hline $\begin{array}{l}\text { Reinstatem } \\
\text { ent }\end{array}$ & RC3D & $1 / 4$ & 6.0 & 4.0 & 6.0 & 6.0 & 4.0 & 4.0 & 4.0 & 6.0 & 4.0 & 4.0 & 6.0 \\
\hline
\end{tabular}

Redundancy constitutes a sufficient ground of dismissal everywhere. The definition of dismissal for 'business reasons' varies, but a reduction in the number of employees, or no further requirement to perform certain work tasks, appears in all legislations.

The scene is more mixed in the case of dismissals due to capability. In Russia and Ukraine, only the state of health or insufficient qualifications constitute sufficient 
grounds for dismissal. In Czech Republic and Slovakia, unsatisfactory performance is explicitly mentioned as an admissible cause instead while, in other countries, grounds for dismissal include 'personal reasons' beyond health and professional qualifications. ${ }^{10}$

In all countries with the exception of Bulgaria, Hungary and Poland, a transfer to a different job has to be attempted prior to dismissal. In Croatia, Czech Republic and Slovenia, the retraining of workers is also explicitly mentioned. When selecting workers to dismiss, employers in Croatia and Lithuania are required to take into account factors like seniority, age and the number of dependants in the employee's family. In Estonia, a detailed hierarchy exists in which preferential treatment is reserved first of all for employee representatives; then to those for whom the job is their principal one; followed by workers with better levels of performance; and, lastly, by those with dependants, the longest seniority, an occupational illness; etc. In Ukraine, several social considerations must be taken into account when choosing among employees with equal labour productivity and qualifications. In Bulgaria, selection in cases of dismissal is not intended to protect some categories but to boost productivity, since it is stated in the labour code that an employer may dismiss 'employees whose positions have not been made redundant in order to retain employees of higher qualifications and better performance' (Art. 329).

An important characteristic concerning the applicability of the rules on dismissal in Croatia and in Slovenia is the relevance of the size of the employer: in Croatia, the rules on the grounds for dismissal, on transfer to a different position and on selection do not apply to employers with twenty or fewer employees; in Slovenia, the rules on transfers do not apply to employers with ten or fewer employees.

A three-month limit is commonly established as the duration of a standard trial period. Bulgaria, Croatia and Slovenia, however, set the limit at six months, while Estonia specifies four months. The maximum duration may be extended to six months in Lithuania in cases specified by the law, while in Ukraine the same is true in special cases and after agreement with the trade union. Ukraine also fixes a lower limit of one month for labourers, while in the Hungarian code the default trial period is one month.

In cases of unfair dismissal, labour codes usually mandate the employer to pay compensation for loss of earnings plus, in some countries, additional penalties, particularly in cases where the employee is not reinstated to their previous position. There are, however, some exceptions. The Slovenian labour code does not directly regulate the subject, but refers to the 'rules of civil law' (Art. 118§1). In cases of non-reinstatement, the criteria to determine compensation in Croatia are the 'duration of the labour relationship, age and the obligation to support dependants' instead of the loss of earnings (Art. 123§1). In the same situation, a lump sum compensation equivalent to six months at the average wage is awarded in Estonia.

The amount of compensation or the penalty that can be awarded is limited in several countries. An upper limit exists in Bulgaria (six months average earnings); in Poland

10 A curiosity about sufficient grounds for dismissal is the explicit mentioning in the Russian code of 'termination of access to State secrets' and, in the Estonian case, the stress put on language skills. 
(in cases of reinstatement, one or two months, depending on the length of notice); and in Ukraine (one year, but potentially longer if legal proceedings take more than one year through no fault of the employee). In addition, a lower limit exists in Croatia, where compensation in cases of non-reinstatement should be between three and eighteen months average earnings; in Hungary (a penalty of between two and twelve months in cases of non-reinstatement); and in Poland (in cases of non-reinstatement, compensation is between two weeks and three months, but no lower than the level of remuneration for the period of notice). In Czech Republic and Slovakia, the employer can ask to reduce or discontinue a compensatory wage if the period over which it should be paid is higher than six and nine months respectively. In Slovakia, the labour code specifies the right to receive compensation equivalent to the period of notice in cases of invalid summary termination; in Hungary, besides compensation for lost earnings, both notice and severance should be paid in these types of cases; while, in Lithuania, severance pay should be added to compensation for lost wages in cases of non-reinstatement.

In the case of illegal dismissal, reinstatement is contemplated in all the countries. However, in Croatia, Hungary, Lithuania, Poland, Slovakia and Slovenia, the labour code explicitly allows the court to refuse it in particular circumstances.

\section{Temporary contracts}

The index on temporary contracts is made up from a sub-index concerning an employment relationship based on a fixed-term contract, and another sub-index concerning the hiring-out of workers by a temporary work agency.

As in the previous section, a table is first presented on the indices; and then a description is provided of the basic aspects of regulation.

Table 6 - Temporary contracts

\begin{tabular}{|c|c|c|c|c|c|c|c|c|c|c|c|c|c|}
\hline & & & ט્ય & $\cong$ & U & 돋 & $\geqq$ & 5 & $\vec{a}$ & $\stackrel{2}{\simeq}$ & $\frac{y}{\omega}$ & $\bar{n}$ & $\overleftrightarrow{s}$ \\
\hline & & Weight & 0.9 & 2.8 & 0.5 & 1.3 & 0.4 & 2.4 & 2.0 & 0.8 & 0.3 & 2.3 & 1.8 \\
\hline $\begin{array}{l}\text { Fixed term } \\
\text { contracts }\end{array}$ & $\mathrm{TC} 1$ & $1 / 2$ & 1.4 & 3.3 & 0.5 & 2.0 & 0.3 & 4.3 & 1.0 & 1.0 & 0.1 & 2.3 & 3.0 \\
\hline $\begin{array}{l}\text { Temporary } \\
\text { work agencies }\end{array}$ & $\mathrm{TC} 2$ & $1 / 2$ & 0.5 & 2.3 & 0.5 & 0.5 & 0.5 & 0.5 & 3.0 & 0.5 & 0.5 & 2.3 & 0.5 \\
\hline
\end{tabular}

Note: for 2004:

$T C-C Z: 1.4 ; E E: 1.5$

TC1-CZ: 1.3; EE: 2.5

TC2 - CZ: 1.5 


\section{Fixed-term contracts}

The extent to which temporary contracts are allowed in addition to 'objective' situations ${ }^{11}$ varies widely. In Hungary, Poland and Slovakia, there are no restrictions on their applicability. In the Czech Republic, limitations exist as regards school graduates and adolescents, but may be over-ridden on the written request of the worker. In Bulgaria a written request, as well as 'specific economic, technological, financial, market and other similar objective reasons' (Labour Code, supplementary provisions, §1) constitutes sufficient ground to establish a fixed-term contract outside 'objective' situations. ${ }^{12}$ In Russia, a fixed-term labour contract can be concluded by employers with up to forty employees, ${ }^{13}$ with employees working part-time and in several other circumstances. On the other hand, Croatia and Ukraine basically limit the use of fixed-term contracts only to 'objective' situations, while Estonia, Lithuania and Slovenia allow fixed-term contracts in some specific additional cases.

\section{Table 7 - Fixed-term contracts}

\begin{tabular}{|c|c|c|c|c|c|c|c|c|c|c|c|c|c|}
\hline & & & $\bigcup_{\infty}^{0}$ & $\underline{\underline{I}}$ & $\mathbf{U}$ & 됟 & $\supseteqq$ & G & $\vec{a}$ & 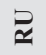 & $\frac{v}{\omega}$ & $\bar{n}$ & $\overleftrightarrow{D}$ \\
\hline & & Weight & 1.4 & 3.3 & 0.5 & 2.0 & 0.3 & 4.3 & 1.0 & 1.0 & 0.1 & 2.3 & 3.0 \\
\hline $\begin{array}{l}\text { Valid cases } \\
\text { other than the } \\
\text { usual } \\
\text { 'objective' }\end{array}$ & $\mathrm{TC} 1 \mathrm{~A}$ & $1 / 2$ & 2.0 & 6.0 & 1.0 & 4.0 & 0.0 & 5.0 & 0.0 & 2.0 & 0.0 & 4.0 & 6.0 \\
\hline $\begin{array}{l}\text { Maximum no. } \\
\text { of successive } \\
\text { contracts }\end{array}$ & TC1B & $1 / 4$ & 1.0 & 0.0 & 0.0 & 0.0 & 0.0 & 6.0 & 4.0 & 0.0 & 0.0 & 0.0 & 0.0 \\
\hline $\begin{array}{l}\text { Maximum } \\
\text { cumulative } \\
\text { duration }\end{array}$ & $\mathrm{TC} 1 \mathrm{C}$ & $1 / 4$ & 0.5 & 1.0 & 0.0 & 0.0 & 1.0 & 1.0 & 0.0 & 0.0 & 0.5 & 1.0 & 0.0 \\
\hline
\end{tabular}

Note: for 2004:

$T C 1 B-E E: 2.0$

TC1C-CZ: 3.0

Limitations also exist with regard to the renewal and duration of temporary contracts. Bulgaria has a particularly tight regulation in that temporary contracts cannot be

11 'Objective' situations refer to specific projects, seasonal work, the replacement of temporarily absent permanent workers (i.e. on sickness or on maternity leave) and for reasons of exceptional workload (OECD, 1999, p. 106).

12 In the Bulgarian context, 'objective' situations are defined as the 'execution of temporary, seasonal or short-term work and activities' (Art. 68§2), as well as the hiring of new employees in enterprises that have been declared bankrupt or are in liquidation.

13 Up to 25 people in the trading and consumer services organisations (Art. 59). 
concluded for periods longer than three years and, in some cases, they cannot be renewed more than once. Moreover, there are also rules concerning their minimum duration. Limitations on the number of successive contracts exist also in Lithuania and were introduced in 2004 in Estonia and Poland. However, the minimum gap for two contracts not to be considered consecutive is quite low, at one month in Poland and Lithuania and two months in Estonia, making the restriction less effective. Rules limiting the duration of a single contract to a maximum of five years are present in Lithuania and Russia, and were introduced in 2004 also in Estonia.

Other countries have limits on the total duration of an employment relationship which is based on fixed-term contracts. The limit in Hungary is five years; in Croatia, it is three years; while in the Czech Republic, a two-year limit, with some exceptions, was introduced in 2004. In Slovakia, the limit of three years to a fixed-term employment relationship does not apply to employers with twenty or fewer employees and in some other cases. Regulation in the Czech Republic and Slovakia is made more severe by the comparatively high minimum gap under which an employment relationship may be considered as continuous, fixed at six months. Also in Slovenia, there is a three-year general limit, which was decreased to two years in 2007 for employers with more than ten employees, and in 2010 for employers with ten or fewer employees. An implicit, even if in some cases very loose, limit on the duration of a fixed-term employment relationship exists also in countries like Bulgaria, Lithuania and Estonia, where limits on the duration of single contracts are combined with restrictions on their renewal.

\section{Temporary work agencies}

Specific regulations on the leasing out of employees by temporary work agencies (TWAs) is present in just some of the countries, usually having been recently introduced.

\section{Table 8 - Temporary work agencies}

\begin{tabular}{|c|c|c|c|c|c|c|c|c|c|c|c|c|c|}
\hline & & & ט్ల & $\cong$ & N & 짖 & 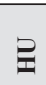 & 5 & 2 & $\vec{z}$ & n & $\bar{n}$ & $\overleftrightarrow{د}$ \\
\hline & & Weight & 0.5 & 2.3 & 0.5 & 0.5 & 0.5 & 0.5 & 3.0 & 0.5 & 0.5 & 2.3 & 0.5 \\
\hline $\begin{array}{l}\text { Types of work } \\
\text { for which } \\
\text { TWAs are legal }\end{array}$ & $\mathrm{TC} 2 \mathrm{~A}$ & $1 / 2$ & 0.0 & 1.5 & 0.0 & 0.0 & 0.0 & 0.0 & 3.0 & 0.0 & 0.0 & 1.5 & 0.0 \\
\hline $\begin{array}{l}\text { Restrictions on } \\
\text { no. of renewals }\end{array}$ & $\mathrm{TC} 2 \mathrm{~B}$ & $1 / 4$ & 2.0 & 2.0 & 2.0 & 2.0 & 2.0 & 2.0 & 2.0 & 2.0 & 2.0 & 2.0 & 2.0 \\
\hline $\begin{array}{l}\text { Maximum } \\
\text { cumulative } \\
\text { duration }\end{array}$ & $\mathrm{TC} 2 \mathrm{C}$ & $1 / 4$ & 0.0 & 4.0 & 0.0 & 0.0 & 0.0 & 0.0 & 4.0 & 0.0 & 0.0 & 4.0 & 0.0 \\
\hline
\end{tabular}

Note: for 2004:

TC2C-CZ: 4.0 
A prohibition usually exists on the hiring out of workers to substitute for workers on strike. Croatia, Poland and Slovenia also make it illegal to hire out workers to perform dangerous jobs and have further restrictions in case the client employer has shed employees in the near past. The use of temporary work in Poland is restricted to 'objective' situations,${ }^{14}$ while the Croatian and Slovenian labour codes explicitly mention the possibility of introducing restrictions through collective agreements.

A rule also exists in these countries fixing the maximum duration of employment gained through a TWA to twelve months. In Croatia and Slovenia, the restrictions are somewhat loose since they are based on the same worker performing the same work, and the minimum gap is just one month. The restrictions are tighter in Poland, where the one year limit applies in any consecutive 36 months.

The Czech Republic also introduced a twelve-month limit in 2004, but this can be disapplied on the request of the worker involved. The regulation on TWAs in Hungary and in Slovakia does not pose relevant restrictions.

\section{Collective redundancy}

The index on collective redundancy is based on direct measures of regulation, without being built on intermediate sub-indices, as in the previous cases. The level of regulation is described below.

\section{Table 9 - Collective dismissals}

\begin{tabular}{|c|c|c|c|c|c|c|c|c|c|c|c|c|c|}
\hline & & & U & $\underline{\underline{I}}$ & U & 됟 & $\geqq$ & 5 & $\vec{a}$ & $\underset{\beth}{\simeq}$ & $\frac{v}{\omega}$ & $\bar{n}$ & $\overleftrightarrow{s}$ \\
\hline & & Weight & 4.1 & 2.5 & 2.6 & 4.0 & 3.4 & 3.6 & 3.3 & 1.9 & 3.0 & 3.3 & 0.0 \\
\hline $\begin{array}{l}\text { Definition of } \\
\text { collective } \\
\text { dismissal }\end{array}$ & CD1 & $1 / 4$ & 4.5 & 3.0 & 4.5 & 6.0 & 4.5 & 4.5 & 4.5 & 1.5 & 3.0 & 4.5 & 0.0 \\
\hline $\begin{array}{l}\text { Additional } \\
\text { notification } \\
\text { requirements }\end{array}$ & CD2 & $1 / 4$ & 6.0 & 3.0 & 3.0 & 3.0 & 6.0 & 6.0 & 3.0 & 0.0 & 3.0 & 4.5 & 0.0 \\
\hline $\begin{array}{l}\text { Additional } \\
\text { delays } \\
\text { involved }\end{array}$ & CD3 & $1 / 4$ & 3.0 & 1.0 & 3.0 & 4.0 & 3.0 & 4.0 & 1.0 & 3.0 & 3.0 & 1.0 & 0.0 \\
\hline $\begin{array}{l}\text { Other special } \\
\text { costs to } \\
\text { employers }\end{array}$ & CD4 & $1 / 4$ & 3.0 & 3.0 & 0.0 & 3.0 & 0.0 & 0.0 & 4.5 & 3.0 & 3.0 & 3.0 & 0.0 \\
\hline
\end{tabular}

There are basically two ways in which a collective dismissal is defined. In the first, 'differentiated' definition, a collective redundancy occurs when, within one month, the

14 Defined as 'seasonal, periodic ad hoc tasks; tasks whose timely performance by the workers of the client employer would not be possible; and tasks normally falling within the ambit of an absent worker employed by the client employer' (Act on the Employment of Temporary Workers, Art. 2). 
number of employees shed is at least ten, for firms whose workforce is between twenty and one hundred; $10 \%$ of the workforce, for firms between one hundred and three hundred; and thirty employees, if the firm has more than three hundred workers. Czech Republic, Hungary and Poland apply exactly this definition. Estonia and Lithuania extend it to firms with less than twenty employees, fixing in this case the threshold at five employees in Estonia and ten in Lithuania.

In the second, 'undifferentiated' definition of collective redundancy, the minimum number of lay-offs is twenty within three months, irrespective of the size of the firm. Croatia applies this definition. Somewhat puzzlingly, in Bulgaria and Slovenia there is a collective redundancy if either of the two definitions apply. ${ }^{15}$ The Russian labour code leaves the definition of collective redundancy to industrial and geographical agreements, while the Ukrainian one does not mention any.

All countries with specific regulation present additional requirements in the case of collective redundancies. Additional actors, usually a labour office, some local administration, or both, have to be involved and the role of actors like employee representatives is deepened compared to individual dismissal cases. This greater involvement of third parties leads everywhere to additional delays in the notification process. Moreover, several labour codes require the drafting of a plan to cope with the redundancy, or at least to negotiate or consult on measures aimed at avoiding or alleviating its consequences. Poland, however, is the only country where additional severance pay is prescribed in cases of collective redundancy.

\section{Conclusions}

In this article, employment protection legislation indicators according to the OECD methodology for 2003-4 have been presented for several central and east European countries. A brief outline of the level of regulation behind the indices has also been provided. The scope of the applicability of the legislative provisions, as well as some aspects of the legislation not captured by the OECD methodology, have been highlighted with the aim of helping towards the correct interpretation of the indices. Moreover, common patterns and outliers have been identified.

In some of the countries under consideration, informal arrangements (like employment without a contract, payments above the official wage) are widespread (see OECD, 2004a; Chapter 5) and should be taken into consideration when assessing the strictness of regulation. However, the lack of detailed indicators on the form and extension of these informal arrangements makes their inclusion into standardised indices rather difficult. This, however, does not invalidate the usefulness of looking at formal rules. On the one side, even in economies with widespread informality, formal rules apply to a relevant size of the labour market. On the other side, the desire to avoid formal rules is often quoted as one of the reasons for informal arrangements, so a comparable indicator like the one presented here can help in shedding light on the roots of informality itself.

15 A firm shedding thirty employees within one month has clearly shed more than twenty employees within three months, thus making part of the first definition simply redundant. 


\section{Bibliography}

Boeri, T and J. F. Jimeno (2005) 'The effects of employment protection: Learning from variable enforcement' European Economic Review 49: 2057-2077.

Botero, J. C, S. Djankov, R. La Porta, F. Lopez-de-Silanes and A. Shleifer (2004) 'The regulation of labor' Quarterly Journal of Economics 119: 1339-1382.

Cazes, S and A. Nesporova (2003) Labour Markets in Transition: Balancing flexibility and security in Central and Eastern Europe Geneva: ILO.

Cazes, S and A. Nesporova (eds.) (2007) Flexicurity - a relevant approach for Eastern Europe? Geneva: ILO.

OECD (1999) Employment Outlook Paris: OECD.

OECD (2004a) A detailed description of employment protection regulation in force in 2003. Background material for the 2004 edition of the OECD Employment Outlook Paris: OECD.

OECD (2004b) Employment Outlook Paris: OECD.

World Bank (2003) Doing Business in 2004: Understanding Regulation Washington, DC: World Bank.

OECD (2004c) Doing Business in 2005: Removing Obstacles to Growth Washington, DC: World Bank.

\section{Appendix - Consulted legislation}

The texts are usually available in the ILO database, NATLEX.

Bulgaria

Labour Code, as amended up to 18 June 2004.

Employment Promotion Act, as amended up to 29 December 2002.

\section{Croatia}

Labour Act, as amended up to 21 September 2004.

Czech Republic

Labour Code, as amended up to 2002.

\section{Estonia}

Employment Contracts Act, as amended up to 22 April 2004.

Hungary

Labour Code, as amended up to Act No. 20/2003. 
Lithuania

Labour Code of 4 June 2002.

Poland

Labour Code, consolidated text, 2005.

Act on the Employment of Temporary Workers, 9 July 2003.

Act on the Special Principles of Terminating Employment with Employees Due to Reasons Not Attributable to Employees, 13 March 2003.

Slovakia

Labour Code, as amended up to July 2004.

Slovenia

Employment Relationships Act, 24 April 2002.

Russia

Labour Code, 31 December 2001.

Ukraine

Labour Code, as amended up to 18 November 2004. 